\title{
Geopolitics and Digital Sovereignty
}

\author{
Ciaran Martin
}

\begin{abstract}
The geopolitical dialogue about technology has, for a quarter of a century, essentially revolved around a single technological ecosystem built by the American private sector. An assumption took hold that, over time, clearer "rules of the road" for this digital domain would take hold. But progress toward this has been surprisingly slow; we sometimes refer to "grey zone" activity, because the rules, insofar as they exist, are fuzzy.

In the meantime, the digital climate is changing. China's technological ambitions are not to compete on the American-built, free, open Internet, but to design and build a completely new, more authoritarian system to supplant it. This is forcing a bifurcation of the Internet, and organizations like the European Union and countries across the world have to rethink whether the regulation of American technology is really where the focus should be, rather than working with the USA to contest China's ambitions.
\end{abstract}

Around a decade ago, it was fashionable in British government circles when discussing the geopolitics of technology to show a picture of Piccadilly Circus in Central London a century earlier. The picture, taken at the dawn of another technological revolution, that of the motorcar, showed various vehicles trapped, pointing in different directions, with no rules to guide who should be going where. The implication was that, over time, humanity learned to develop new "rules of the road" for harnessing technology. Over time, it was asserted, the same would be true of the new digital technologies.

The position is much more complicated now for two reasons. First, setting the rules for the Internet as we understood it then has proved harder and slower than many thought 10 years ago. Second, back then we were talking about a single model of Internet-led technology which was the creation of, by and large, the American private sector. Now there are at least three competing blocs, each seeking supremacy

C. Martin $(\varangle)$

Blavatnik School of Government at the University of Oxford, Oxford, UK

e-mail: ciaran.martin@bsg.ox.ac.uk 
or at least a competitive position with that model. So before the governance of the American-led model properly settled down, a new geopolitical contest is underway.

Let us first look at the perhaps surprisingly slow progress in the governance of the American-led model. The absence of international rules and standards in many areas of digital life remains a concern for many of America's Western allies. Tax remains problematic: in the summer of 2020, talks between the USA and the European Union on the taxation of digital services broke down; in 2021, the new Biden administration was still challenging the attempts of the UK, now outside the European Union, to introduce a digital services tax which would apply mostly to American companies. The UK, the other non-US Five Eyes, and the EU institutions remain at loggerheads with Silicon Valley over the security and law enforcement implications of end-to-end encryption, with increasingly vocal frustration at the powerlessness of Western governments to reverse the move toward its ubiquity. There have been some movements toward mutually recognized standards in digital trade and data protection. But overall it is hard to claim that the governance of the "free" Internet pioneered on the US West Coast in the late 1990s has progressed much.

Moreover, there are few if any common understandings, let alone rules, about acceptable and unacceptable conduct on that free and open Internet. The first phase of online geopolitical competition has been played on Western or, more precisely, American terms: the USA has most of the infrastructure, the companies, the influence in standards bodies, and much else. So hostile forces, like Russia, when seeking to undermine the USA, are doing so within the digital environment created by the Americans, rather than competing with it. They have exploited its ambiguities and vulnerabilities in a series of what have become known as "grey zone" operations. The zone is "grey" precisely because norms have not been established.

True, the United Nations Open-Ended Working Group on cyber norms unexpectedly reached a unanimous consensus in its third and final round in early 2021. But it is too early to tell whether this compromise will have any lasting impact in terms of the quest for rules of the road in cyberspace. In the meantime, the characterization of a supply chain intrusion for espionage purposes (the so-called Holiday Bear campaign carried out against the SolarWinds company and others) as an act of war by senior members of the US Congress - the sort of activity routinely carried out by Western intelligence services for information gathering purposes-demonstrates the chasm in understanding when it comes to norms. There remains no Western consensus on acceptable activity in cyberspace: for example, Microsoft's quest for a Digital "Geneva Convention" has never attracted serious support from its own government in Washington or any of the USA's most important allies. Western governments, particularly the Five Eyes, show no particular appetite for them.

So the rules of the road remain largely absent. But in the meantime, the geopolitics have evolved significantly. A decade ago, however, one almost universal assumption was that the geopolitics of the new technological age would remain a contest on America's terms. Silicon Valley had no strategic competitor. Moreover, the apparent success of the open and free model was seen as a grave threat to authoritarian regimes seeking to challenge the USA, so shaping the global rules would extend liberal, democratic values. 
China has comprehensively overturned in the last decade. Public confidence in the West in its own digital model has wobbled as citizens have increasingly fretted about a range of online harms like online abuse of children, disinformation, monopolistic practices, and cyberattacks. In contrast, and crucially, the first credible challenger model to US-led technology has emerged out of Beijing and the Chinese Communist Party.

The rapid development of Chinese technology has exploded two of the great founding myths of the digital age: that there is no way for states to assert control over the Internet and that the Internet is global and cannot be regionalized. China has long passed the stage where new digital services were a threat to the regime; ${ }^{1}$ it has now co-opted new technology into capabilities which further its authoritarian control. And in doing so, it has demonstrated, for example, with its so-called Great Firewall, that the Internet can have borders after all. As Western confidence in America's technology started to wobble, China's self-confidence in its own development, set out with brutal clarity in its 2015 plan known as Made in China 2025 with designs to attain supremacy in many of the key technologies of the future, was published for all to see.

It is now increasingly evident that the USA and China are engaged in an epochdefining struggle for technological supremacy with huge implications for the geopolitics of the rest of the century. Decoupling of supply chains, already underway with the USA's largely successful campaign to bar Huawei from next-generation telecommunications networks, has now been accelerated by the pandemic. New battlegrounds are emerging: the standards bodies that set technical rules for data transit and infrastructure design and the control of rare-earth metals and other raw materials for hardware among them.

The clash of these two tech titans has brought into sharp focus the relatively new concept of digital sovereignty across various parts of the globe. It can be argued that until recently only the USA was digitally sovereign: in that it could rely pretty much entirely on itself to sustain its digital ecosystem (though there are gaps; the USA's lack of indigenous hardware providers for telecoms infrastructure was exposed during the $5 \mathrm{G}$ controversies). But China is becoming digitally sovereign too, not least because the imposition of US sanctions aimed at slowing its technological development has incentivized it never to be reliant on supplies form outside China again. $^{2}$

What of the rest of the world? The most intriguing potential third power bloc is the European Union. The EU is the technological era's great paradox. The USA and China do not really talk about digital sovereignty, but are, by and large, digitally sovereign. The EU talks a lot—and increasingly_about digital sovereignty, but it is

\footnotetext{
${ }^{1}$ For an account of how the Chinese Communist Party wrought control over online communications in China, see Consent of the Networked: The Worldwide Struggle for Internet Freedom (Rebecca MacKinnon, 2013).

${ }^{2}$ For a superb account of this trend, see Dan Wang, Annual Letter, 2019 https://danwang.co/2019letter/
} 
very far from digital sovereignty. Two telecommunications equipment giants aside, the European continent of half a billion of the world's wealthiest Internet users has precious little home-grown technological capability. Insofar as it is a tech superpower, it is only a regulatory one. There is obviously an attempt to ground this regulatory posture in digital humanism, but without the industrial capability, this already complicated task is even harder.

Brussels policy is currently facing in two different directions. In July 2020, the German government, in its official program for its presidency of the European Council, announced its intention "to establish digital sovereignty as a leitmotiv of European digital policy" (Pohle and Thie 2020). In its cyber security strategy of the end of that year, the Commission set out, for the first time, some serious ideas on how the development of European technology might take root. But in the same month, the Commission published an overture to the incoming Biden administration proposing economic cooperation on technology, including the establishment of a Transatlantic Trade and Technology Council. This seemed to be a recognition that digital sovereignty in Europe could not be achieved quickly (if it can be achieved at all). Therefore, given the need to align with one of the two genuine technology superpowers, the Americans were the only option, particularly after the departure of President Trump who famously cared little for the USA's alliances in Europe.

Three other more disparate groups of countries will be important in this great geopolitical contest. One, likely to be of great interest to the Biden administration not least because of Europe's ambivalence toward US technology and its current administrative paralysis over coronavirus vaccines, are a set of rich, hi-tech democracies across the Five Eyes partnership and Asia (Japan, Singapore, South Korea). None of these have any serious aspirations for digital sovereignty, though Japan and Korea have some serious techno-industrial clout. But they will be keen to align with Washington to counter China's technological ambitions. The challenge is that such an effort does not work like a security alliance: aligning commercial strategies is harder than forming a military pact.

Then there is a group of authoritarian countries who dislike the US technological model every bit as much as China does, but have no capabilities of their own. Russia and Iran are examples of this. They may pursue a version of digital sovereignty which is, in effect, Chinese-style control over the use of the technology without the increasingly Chinese control over the ownership of it. Russia has held some at least partially successful experiments in "disconnecting" itself from the Internet, though a recent test seems to have backfired and hit the Russian government's own infrastructure. In time, such countries may become enthusiastic champions of China's digital model (Russia is already showing signs it may be heading in this direction).

Then, finally, there is the rest of the world: mostly middle- and lower-income countries with no serious expectation of digital sovereignty. Many of these countries increasingly fear being caught between the USA and China and having to choose. For this section of the globe's population which is where much digital growth is expected as gaps in digital inclusion close, the term "digital sovereignty" rings hollow amidst the struggle of the two technological heavyweights. As Deborah M. Lehr of the Paulson Institute put it in 2019, "if a new economic Iron Curtain is 
to fall, it will be in areas like the Middle East and Africa" (Lehr 2019). Such countries will worry less about the West's ongoing struggles to write rules of the road for America's Internet and more about the implications of this splintering of the technological globe.

\section{References}

Pohle, Julia and Thie, Thorsten (2020). "Internet Policy Review" Digital Sovereignty 4(9).

Lehr, Deborah M. (2019). How the US-China Tech War Will Impact The Developing World. Published in The Diplomat, 23 February 2019.

Open Access This chapter is licensed under the terms of the Creative Commons Attribution 4.0 International License (http://creativecommons.org/licenses/by/4.0/), which permits use, sharing, adaptation, distribution and reproduction in any medium or format, as long as you give appropriate credit to the original author(s) and the source, provide a link to the Creative Commons license and indicate if changes were made.

The images or other third party material in this chapter are included in the chapter's Creative Commons license, unless indicated otherwise in a credit line to the material. If material is not included in the chapter's Creative Commons license and your intended use is not permitted by statutory regulation or exceeds the permitted use, you will need to obtain permission directly from the copyright holder.

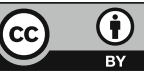

